\title{
Assessment of the microbiological quality of fresh produce on sale in Sicily, Italy: preliminary results
}

\author{
Cinzia Cardamone ${ }^{1 *}$, Aurora Aleo ${ }^{2}$, Caterina Mammina², Giuseppa Oliveri ${ }^{1}$ and Anna Maria Di Noto
}

\begin{abstract}
Background: Fresh produce occupies an increasingly important place in the human food supply because of its health-promoting nutritional properties. Most fresh produce is eaten raw or after minimal processing and, consequently, pathogen contamination can represent a serious health risk. There has been an increase in foodborne outbreaks and cases associated with fresh produce, but literature data about the prevalence of pathogen contamination are inconsistent. This study was undertaken to assess the hygienic quality and the prevalence of the most common bacterial pathogens in fresh produce sold in retail markets in Sicily. A total of 125 samples of different types of vegetables were examined by standardized microbiological methods.

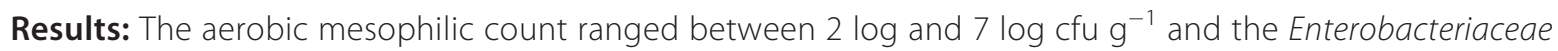
counts between $<1 \log$ and $6 \log \mathrm{cfu}^{-1}$, with statistically significant differences between unprocessed and minimally processed products $(p<0.05)$. Escherichia coli was detected only in leaf vegetables at a concentration of $2 \log -3 \log \mathrm{cfu} \mathrm{g}^{-1}$. Enterococci were found at a concentration of $2 \log -4 \log \mathrm{cfu} \mathrm{g}^{-1}$. Coagulase positive Staphylococci and sulphite-reducing Clostridia were not detected in any sample. Three samples tested positive for Listeria monocytogenes, Yersinia enterocolitica and Salmonella veneziana.
\end{abstract}

Conclusion: Our study provides updated data on the microbiological quality of retail vegetables and confirms the need to implement strategies to increase microbial safety of fresh produce.

Keywords: Fresh produce, Vegetables, Food safety, Hygiene quality, Foodborne pathogens

\section{Background}

Fresh produce plays an important role in the human diet because of its health-promoting nutritional characteristics [1]. Its antioxidants content in particular, is thought to be able to protect human cells from the attack of free radicals, which is in turn involved in the etiopathogenesis of most chronic diseases [2-4]. It is also hypothesized that vegetable antioxidants may bring further protective health effects through various mechanisms, acting as inducers of mechanisms related to cell maintenance, DNA repair and longevity [5-7]. This awareness has gradually resulted in the last years in a generalized shift of eating habits towards an increasing intake of fruits and vegetables. The data provided by the World Health Organization (WHO)/Food and Agriculture Organization (FAO) showed a $4.5 \%$ yearly increase in fruit and vegetable

\footnotetext{
* Correspondence: cinzia.cardamone@izssicilia.it

'Istituto Zooprofilattico Sperimentale della Sicilia "A. Mirri", via G. Marinuzzi 3, 90129 Palermo, Italy

Full list of author information is available at the end of the article
}

consumption between 1990 and 2004 [8]. Outbreaks of foodborne illnesses associated with the consumption of fresh produce are simultaneously increasing in frequency. In developed countries, changes in consumption patterns, raising numbers in elderly and immunocompromised consumers and the growing import of vegetables from countries with poor sanitary conditions have likely contributed to this epidemiological trend [9]. Moreover advanced diagnostic methods and surveillance systems have enhanced identification of fresh produce as sources of foodborne disease [10].

As a consequence, food safety of fresh produce is a matter of increasing concern; indeed, microbial contamination may occur during any of the steps in the farm-totable continuum from environmental, animal or human sources [11-15].

Minimally processed vegetables (MPV) are processed to increase their functionality without changing their fresh properties. Preparation procedure generally includes processes such as washing, peeling, cutting, trimming and/or 
slicing [16]. Salmonella spp., Shigella spp., pathogenic Escherichia coli, Listeria monocytogenes and Campylobacter spp. are the most important vegetable-borne pathogens $[11,15]$. Data from the recent literature are inconsistent about the prevalence of these pathogens in vegetables, due to significant differences between studies in the sizes and place of sampling, local fresh produce type, seasonality and analytical methods [8]. Some authors report Salmonella spp. in less than $8 \%$ of the analyzed samples, Campylobacter spp. in $3.1 \%$ of lettuce, but $E$. coli $\mathrm{O} 157$ in up to $25 \%$ of cabbages and $19.5 \%$ of coriander and L. monocytogenes in up to $7 \%$ of cabbages, $22.7 \%$ of leafy vegetables and $20 \%$ of lettuce $[8,17]$. Other reports describe prevalence lower than 1-2\% for E. coli O157, Campylobacter spp. and Salmonella spp. [18].

The aim of the study was to assess the hygienic quality and the prevalence of the most common pathogens in fresh produce, minimally processed vegetables (MPVs) and unprocessed vegetables (UVs), sold in retail markets in Sicily, Italy.

\section{Results and Discussion \\ Microbial flora}

The microbiological results of UVs are summarized in Table 1. The Aerobic Mesophilic Count (AMC) levels ranged between $2 \log$ and $6 \log \mathrm{cfu} \mathrm{g}^{-1}$ and the Enterobacteriaceae counts between $2 \log$ and $6 \log \mathrm{cfu} \mathrm{g}^{-1}$, except for the seed and bulb vegetable sample $(<1 \log$ $\mathrm{cfu}^{-1}$ ). Escherichia coli was found only in leaf (lettuce) at a concentration of 2-3 log cfu $\mathrm{g}^{-1}$. Enterococci were found in leaf (lettuce), flower (cauliflowers) and fruit vegetables (marrow) at a concentration of 2-3 log cfu g ${ }^{-1}$.

MPVs (Table 2) yielded AMC values between 5-7 log $\mathrm{cfu}^{-1}$, except for the fruit vegetable samples $(<1 \log \mathrm{cfu}$ $\mathrm{g}^{-1}$ ) (Table 2).

Enterobacteriaceae and E. coli were detected in leaf vegetables (salad and spinach) and in one chicory sample. Enterococci were detected in salad samples and in a pumpkin sample at a concentration of $2-4 \log \mathrm{cfu} \mathrm{g}^{-1}$.
Coagulase positive Staphylococci and sulphite-reducing Clostridia were not detected in any sample.

The samples of the leaf vegetables had significantly higher AMC $(p<0.001)$ and Enterobacteriaceae $(p=0.01)$ counts than fruit vegetables. The differences of the $E$. coli counts between the two categories of vegetables were not statistically significant $(p=0.08)$, probably due to the lowest proportion of contaminated samples.

The colonies isolated from Violet Red Bile Glucose Agar proved to belong to the following bacterial species: Klebsiella oxytoca, Pantoea spp., Serratia odorifera, Serratia liquefaciens, Serratia ficaria, Raoultella terrigena, Rahnella aquatilis and Erwinia spp.

Our findings showed that leaf vegetables had the highest bacterial counts among vegetable products, with particular reference to the mesophilic bacteria, Enterobacteriaceae, E. coli and Enterococci. Despite the high counts, no products reported visible signs of organoleptic alterations. Accordingly, Ragaert et al. [19] reported that evident organoleptic alterations occur in vegetables only when bacterial count is higher than 7 or $8 \log \mathrm{cfu} \mathrm{g}^{-1}$.

High bacterial counts could likely be associated with the morphology of leaves which have a broad and rather rough surface. Indeed, both the large surface, easily coming in contact with the ground and the irrigation water, and its roughness facilitate the accumulation of dirt and adhesion of bacteria, as reported by some authors $[10,20,21]$. Our results agree with those reported by literature that identify salads as the most contaminated vegetable product. Seow et al. [10] in a study conducted on fresh vegetables and fruit samples, both UVs and MPVs, showed that samples of lettuce, along with sprouts, have the highest levels of mesophilic bacteria and coliforms. They reported mesophilic bacteria counts ranging from 3.4 to $7.3 \mathrm{log} \mathrm{cfu} \mathrm{g}^{-1}$ and coliforms between 1.6 and $5.9 \log \mathrm{cfu} \mathrm{g}^{-1}$, with $50 \%$ of samples containing more than $5 \mathrm{log} \mathrm{cfu} \mathrm{g}^{-1}$ of coliforms. Allende et al. [22], while assessing the microbiological quality of red lettuce marketed in Spain, found $3.67 \log \mathrm{cfu} \mathrm{g}^{-1}$ of coliforms. In Canada, Bohaychuk et al. [23] assessed the

Table 1 Microbiological findings obtained from 85 samples of UVs (in log cfu $\mathrm{g}^{-1}$ )

\begin{tabular}{llllll}
\hline Vegetable & AMC (range) & $\begin{array}{l}\text { Enterobacteriaceae } \\
\text { (range) }\end{array}$ & $\begin{array}{l}\text { E. coli } \\
\text { (range) }\end{array}$ & $\begin{array}{l}\text { Enterococci } \\
\text { (range) }\end{array}$ & $\begin{array}{l}\text { Clostridia } \\
\text { staphylococci }\end{array}$ \\
\hline Seed vegetables & $2-4$ & $<1-3$ & $<1$ & $<1$ & $<1$ \\
Leaf vegetables & $2-6$ & $2-6$ & $<1-3$ & $<1-2$ & $<1$ \\
Fruit vegetables & $3-6$ & $2-3$ & $<1$ & $<1-3$ & $<1$ \\
Stem vegetables & $2-6$ & $2-3$ & $<1$ & $<1$ & $<1$ \\
Flower vegetables & $4-5$ & $2-3$ & $<1$ & $<1$ \\
Root vegetables & $4-5$ & $2-3$ & $<1$ & $<1$ \\
Bulb vegetables & $4-5$ & $<1-3$ & $<1$ & $<1$
\end{tabular}


Table 2 Microbiological findings obtained from 40 samples of MPVs (in log cfu $\mathrm{g}^{-1}$ )

\begin{tabular}{lllllll}
\hline Vegetable & AMC (range) & $\begin{array}{l}\text { Enterobacteriacea } \\
\text { (range) }\end{array}$ & $\begin{array}{l}\text { E. coli } \\
\text { (range) }\end{array}$ & $\begin{array}{l}\text { Enterococci } \\
\text { (range) }\end{array}$ & $\begin{array}{l}\text { Clostridia } \\
\text { Coagulase positive } \\
\text { staphylococci }\end{array}$ \\
\hline Leaf vegetables & $5-7$ & $<1-5$ & $<1-3$ & $<1-3$ & $<1$ & $<1$ \\
Root vegetables & $6-7$ & $<1$ & $<1$ & $<1$ & $<1$ & $<1$ \\
Fruit vegetables & $<1-7$ & $<1$ & $<1$ & $<1-4$ & $<1$ & $<1$ \\
\hline
\end{tabular}

prevalence of $E$. coli in fresh vegetables produced in Alberta and found this organism in $8.2 \%$ of lettuce, spinach and carrots samples with counts ranging from 0.48 to $3.04 \log \mathrm{MPN} \mathrm{g}^{-1}$. About UVs, it can be observed that Enterobacteria were present in almost all samples; counts higher than $2 \log \mathrm{cfu} \mathrm{g}^{-1}$ were detected in $97.6 \%$ of the examined samples. However, this bacterial counts does not appear to be of special concern, as the identified species are commonly found in soil, water and in environments characterized by an excessive organic load. Thus, such microbial flora can be primarily attributed to an environmental source $[10,24]$. Regarding E. coli contamination, there was a low percentage of contaminated UVs samples (3.5\%) with bacterial counts ranging from 2 to $3 \log \mathrm{cfu} \mathrm{g}^{-1}$. Moreover, in our study, 5.0\% of MPVs were contaminated by $E$. coli, but only one sample did not comply with the limits set by law [25], as the bacterial count was $4 \log \mathrm{cfu} \mathrm{g}^{-1}$. Of interest, E. coli is included in the Regulation (EC) No 2073/2005 as the indicator of quality of hygienic processing for MPVs (pre-cut fruit and vegetables) [25]. Our data agree with those reported by literature, indicating low percentages of vegetable products contaminated with $E$. coli and with low counts. Abadias et al. [21] found E. coli in 7.1\% of vegetable products of UVs and in $11.4 \%$ of products of MPVs, with only $0.8 \%$ of products exceeding $100 \mathrm{MPN} \mathrm{g}^{-1}$. Santos et al. [24] found $2.6 \%$ of contaminated samples (lettuce and spinach) with counts ranging between 1 and $2 \log$ cfu g $\mathrm{g}^{-1}$.

\section{Bacterial pathogens}

Our results showed a total of three samples out of 125 , one UV and two MPVs, yielding foodborne pathogens, in particular Salmonella spp., L. monocytogenes and $Y$. enterocolitica.

All samples tested negative for Campylobacter spp., Shigella spp. and E. coli O157.

Salmonella veneziana was detected in one sample of green salad (UVs). It yielded also an AMC of $6.98 \mathrm{log}$ $\mathrm{cfu}^{-1}$, an Enterobacteriaceae count of $5.73 \log \mathrm{cfu} \mathrm{g}^{-1}$, an E. coli count of $3.95 \log \mathrm{cfu} \mathrm{g}^{-1}$ and an Enterococci count of $2.07 \mathrm{log} \mathrm{cfu} \mathrm{g}^{-1}$ (Table 3).

Listeria monocytogenes serotype $4 \mathrm{~b}$ was detected in association with $L$. innocua in a pumpkin sample. This was a minimally processed vegetable sample and the quantitative analysis yielded a concentration of Listeria less than $1 \log \mathrm{cfu} \mathrm{g}^{-1}$. This sample had also an AMC of $6.47 \log \mathrm{cfu} \mathrm{g}^{-1}$ (Table 3).

Yersinia enterocolitica O:3 was detected in a MPV spinach sample which yielded also Aeromonas hydrofila. Moreover, this sample showed an AMC of $6.95 \mathrm{log} \mathrm{cfu} \mathrm{g}^{-1}$ and an Enterobacteriaceae count of $4.90 \mathrm{log} \mathrm{cfu} \mathrm{g}^{-1}$ (Table 3).

Literature data are conflicting about the prevalence of pathogens in vegetables. Studies on UV fresh vegetables in USA, United Kingdom, and Malaysia showed a highly variable prevalence of Salmonella contamination, with values between $0 \%$ and $35 \%$, respectively $[18,26,27]$. During 2005-2006, in Spain, Abadias et al. [21] detected Salmonella spp. and L. monocytogenes, respectively, in $1.3 \%$ and $0.7 \%$ of their samples. Furthermore, Sant'Ana et al. [28] studied the prevalence of Salmonella spp. in MPVs and found that $0.8 \%$ of the samples was contaminated by serotypes Enteritidis and Typhimurium. In Norway, Johannessen et al. [29] isolated L. monocytogenes and $Y$. enterocolitica, respectively, in $0.3 \%$ and $3 \%$ of the samples. Santos et al. [24] tested MPV samples for pathogens and found A. hydrophila in 11 samples (7.3\%), L. monocytogenes in one sample of spinach (0.6\%) and $L$. innocua in a further sample of spinach and salad (1.3\%). Pathogen contamination in MPVs suggests failures in risk assessment and management systems in processing facilities, where contamination sources may be very heterogeneous: soil, irrigation waters and processing environment. Moreover washing and disinfection may not provide a complete removal of pathogens from MPVs. It is, indeed, of the uttermost importance to accurately follow Good Manufacturing Practices (GMP) through the entire production cycle (from primary production to distribution), in order to consistently meet food safety objectives.

\section{Conclusion}

Community regulation about the hygienic quality of vegetables is quite recent. Regulation (EC) 2073/2005 and subsequent modifications, has established microbiological limits for some types of vegetable products. In particular for ready-to-eat pre-cut fruits and vegetables, E. coli and L. monocytogenes/Salmonella spp. were defined as microbiological criteria of process hygiene and food safety, respectively. No further specific regulation is in place in EU for other types of vegetable products, 
Table 3 Characteristics of vegetables which tested positive for foodborne pathogens

\begin{tabular}{|c|c|c|c|c|c|c|}
\hline Vegetable & Type & Microrganism & $\begin{array}{l}\text { AMC } \\
\log _{\mathrm{cfu} \mathrm{g}^{-1}}\end{array}$ & 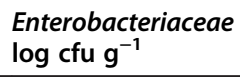 & $\begin{array}{l}\text { E. coli } \\
\text { log cfu g }^{-1}\end{array}$ & $\begin{array}{l}\text { Enterococci } \\
\operatorname{log~cfu~g}^{-1}\end{array}$ \\
\hline \multirow[t]{2}{*}{ Pumpkin } & MPV & L. monocytogenes & 6.47 & $<1$ & $<1$ & $<1$ \\
\hline & & L. innocua & & & & \\
\hline \multirow[t]{2}{*}{ Spinach } & MPV & Y. enterocolitica & 6.95 & 4.90 & $<1$ & $<1$ \\
\hline & & A. hydrofila & & & & \\
\hline Green salad & UV & Salmonella spp. & 6.98 & 5.73 & 3.95 & 2.07 \\
\hline
\end{tabular}

such as UVs, or other pathogen microorganisms (e.g. Yersinia spp., Campylobacter spp.). Even though there are worldwide reports of outbreaks associated with the consumption of vegetable products, data concerning the microbial contamination level of these foodstuffs are still few and discrepant; in particular this lack of knowledge affects most MPV and UV vegetables.

This work is to some extent a preliminary investigation which will allow for targeting specific groups of products with a higher risk profile in the next future.

\section{Methods}

Vegetable samples

One hundred twenty-five vegetable samples, (40 MPVs and $85 \mathrm{UVs}$ ), were collected from four supermarkets and two greengrocer's shops (Table 4) in Palermo district.

These variety of places allowed products commonly available to consumers to be sampled, thus making results more representative.

Sampling was carried out by randomly taking 250-300 g of sample from each box, according to the Regulation (EC) No 333/2007 [30]. The samples of MPVs were bought within 1-2 days from their packaging. All samples were subjected to microbiological analysis after an inspective check to evaluate the

Table 4 Number and type of vegetable samples under analysis

\begin{tabular}{llll}
\hline Vegetable* $^{*}$ & $\begin{array}{l}\text { No. of } \\
\text { samples }\end{array}$ & $\begin{array}{l}\text { No. of UV } \\
\text { samples }\end{array}$ & $\begin{array}{l}\text { No. of MPV } \\
\text { samples }\end{array}$ \\
\hline Leaf vegetables & 58 & 28 & 30 \\
Bulb vegetables & 3 & 3 & $/$ \\
Root vegetables & 13 & 7 & 6 \\
Fruit vegetables & 37 & 33 & 4 \\
Flower vegetables & 4 & 4 & $/$ \\
Stem vegetables & 7 & 7 & $/$ \\
Seed vegetables & 3 & 3 & $/$ \\
Total & 125 & 85 & 40
\end{tabular}

*Leaf vegetables (lettuce, chicory, spinach), bulb vegetables (garlic), root vegetables (carrot), fruit vegetables (aubergine, tomato, marrow, pumpkin), flower vegetables (cauliflower), stem vegetables (fennel, celery), seed vegetables (sesame). following features: for UVs, freshness and absence of spoilage signs; for MPVs, labeling information and presence of extraneous materials into the wrapping.

The samples were transferred to the laboratory in cooler boxes at temperature between $1^{\circ} \mathrm{C}$ and $8^{\circ} \mathrm{C}$ and the microbiological assays were performed within $24 \mathrm{hrs}$ since the sample collection.

\section{Enumeration of bacteria}

Each sample was analyzed for Aerobic Mesophilic Count (AMC), Enterobacteriaceae, E. coli $\beta$-glucuronidase positive, coagulase positive Staphylococci, sulphite-reducing anaerobic organisms, Enterococci and L. monocytogenes. Microbial analyses were carried out using the standard methodologies described in Table 5.

Thirty $\mathrm{g}$ of each sample were weighed into sterile stomacher bags and homogenized with $270 \mathrm{ml}$ Saline Peptone solution ( $\mathrm{NaCl} 8.5 \mathrm{~g} \mathrm{l}^{-1}$, Peptone $1.0 \mathrm{~g} \mathrm{l}^{-1}$ ) in a stomacher (Type 400; Seward London, UK). Decimal dilutions were prepared with the same diluent and $1 \mathrm{ml}$ of each was used as inoculum. Results were reported in terms of colony forming units $\left(\mathrm{cfu} \mathrm{g}^{-1}\right)$.

A laboratory internal method (Rapid Enterococcus Agar, $44^{\circ} \mathrm{C}, 48 \mathrm{hrs}$, followed by catalase and esculin hydrolysis test on the suspected colonies) (Biorad) was used for Enterococci.

Representative colonies of all discernible morphologies were picked up from the Violet Red Bile Glucose Agar plates, subcultured and biochemically identified by API 20E (bioMerieux, Marcy-l'Etoile, France).

\section{Isolation of foodborne pathogens}

Twenty five g of each sample were weighed into sterile stomacher bags and homogenized with $225 \mathrm{ml}$ of enrichment broth for each pathogen.

Shigella spp. detection was performed by the ISO 21567:2004 method consisting of a first enrichment step in Shigella Broth with novobiocin at $41.5^{\circ} \mathrm{C}$ for $16-20 \mathrm{hrs}$, followed by subculture in MacConkey Agar, Xylose Lysine Deoxycholate (XLD) Agar and Hektoen Enteric Agar at $37^{\circ} \mathrm{C}$ for $20-24$ hrs.

Yersinia enterocolitica detection was performed by the ISO 10273:2003 method with a selective enrichment in 
Table 5 Standard methods used for microbial analyses

\begin{tabular}{lll}
\hline Determination & Methodology & Medium, temperature and incubation time \\
\hline Aerobic Mesophilic Count (AMC) & ISO 4833:2003 & Plate Count Agar, $30^{\circ} \mathrm{C}, 72 \mathrm{hrs}$ \\
Enterobacteriaceae & ISO 21528-2:2004 & Violet Red Bile Glucose Agar, $37^{\circ} \mathrm{C}, 24 \mathrm{hrs}$ \\
E. coli $\beta$-glucuronidase positive & ISO 16649-2:2010 & Tryptone Bile Glucuronide Agar, $44^{\circ} \mathrm{C}, 24 \mathrm{hrs}$ \\
Coagulase positive staphylococci & ISO 6888-1:1999 Amend. 1:2003 & Baird Parker Agar, $37^{\circ} \mathrm{C}, 24-48 \mathrm{hrs}$ \\
Sulphite-reducing anaerobic organisms & ISO 15213:2003 & Iron Sulphite Agar, $37^{\circ} \mathrm{C}, 24 \mathrm{hrs}$ \\
L. monocytogenes & ISO 11290-2:1998 & ALOA Agar, 37 $\mathrm{C}, 24-48 \mathrm{hrs}$ \\
\hline
\end{tabular}

Pepton Sorbitol Bile Salts (PSB, Biolife) at $25^{\circ} \mathrm{C}$ for 5 days and an additional selective enrichment in Irgasan Ticarcillin (ITC, Biolife) Broth at $25^{\circ} \mathrm{C}$ for 48 hrs. The PBS broth was inoculated in Cefsulodin Irgasan Novobiocin Agar, while ITC Broth was streaked onto Salmonella-Shigella Agar with Sodium Deoxycholate and Calcium Chloride (Biolife, Sigma). All the plates were incubated at $30^{\circ} \mathrm{C}$ for $24 \mathrm{hrs}$.

Campylobacter spp. detection was performed by the ISO 10272-1:2006 method with a selective enrichment in Bolton Broth at $37^{\circ} \mathrm{C}$ for $4-6$ hrs and then at $41.5^{\circ} \mathrm{C}$ for 48 hrs microaerobically. The Bolton Broth was inoculated in modified Campylobacter Charcoal Differential Agar (Biolife) and Skirrow Agar at $41.5^{\circ} \mathrm{C}$ for $48 \mathrm{hrs}$ microaerobically.

Detection of Salmonella spp., L. monocytogenes and E. coli $\mathrm{O} 157$ was carried out by an enzyme linked fluorescent assay (ELFA) in an automatic system VIDAS (bioMerieux, Marcy-l'Etoile, France). In particular, the following methods were used:

- for Salmonella spp., the AFNOR BIO 12/23-05/07 method including a pre-enrichment step in Buffered Peptone Water at $37^{\circ} \mathrm{C}$ for $16-20 \mathrm{hrs}$ and a subsequent step performed by VIDAS Immuno-Concentration Salmonella II (ICS2). The samples which tested positive were then confirmed by subculturing them in XLD Agar at $37^{\circ} \mathrm{C}$ for $24 \pm 3 \mathrm{hrs}$;

- for L. monocytogenes, the AFNOR BIO 12/11-03/04 method was performed with Half Fraser broth at $30^{\circ} \mathrm{C}$ for $24-26 \mathrm{hrs}$ and then Fraser Broth (FB) at $37^{\circ} \mathrm{C}$ for $24-26 \mathrm{hrs}$. One portion of the FB culture was then used for the L. monocytogenes VIDAS test (LMO2). The samples which tested positive were then confirmed by subculturing them in Listeria Aloa Agar (ALOA) (Biolife) and Listeria Oxford Agar at $37^{\circ} \mathrm{C}$ for $24 \pm 3 \mathrm{hrs}$;

- for E. coli O157, the AFNOR BIO 12/8-07/00 method was used with a first step in Tryptone Soya Broth with novobiocin, incubated at $41.5^{\circ} \mathrm{C}$ for 6-7 hrs, and a second step in MacConkey Broth with cefixime-potassium tellurite, incubated at $37^{\circ} \mathrm{C}$ for $18 \mathrm{hrs}$. After heating at $95-100^{\circ} \mathrm{C}$, an aliquot was used for VIDAS (ECO).
All culture media were from OXOID except otherwise stated.

\section{Biochemical and serological identification}

The suspected Salmonella spp. colonies were subcultured for purity and identified by the Biolog automatic system (Biolog Inc., Hayward, CA). All suspected Listeria spp. colonies were submitted to catalase and $\beta$-hemolysis test and definitively identified by the Biolog automatic system.

Listeria monocytogenes isolates were subjected to serotyping by specific antisera (Denka Seiken, Tokio, Japan). The suspected Yersinia spp. colonies were submitted to oxidase, urease, indole test and definitively identified by API 20E (bioMerieux, Marcy-l'Etoile, France).

Serotyping of Salmonella, L. monocytogenes and $Y$. enterocolitica isolates was carried out at the Regional Reference Centre for Enteric pathogens, University of Palermo, Italy, by using commercial antisera (Staten Serum Institut, Denmark, and Denka-Seiken, Japan).

\section{Statistical analysis}

Quantitative values were categorized in two classes (equal/higher $v s$ lower than the median value for AMC and Enterobacteriaceae and detected $v s$ undetected for E. coli). Association between these classes and the most represented type of vegetables was assessed by contingency tables. Statistical significance was calculated by the chi-square test or the Fisher's exact test, when appropriate. $p$ value less than 0.05 was considered statistically significant.

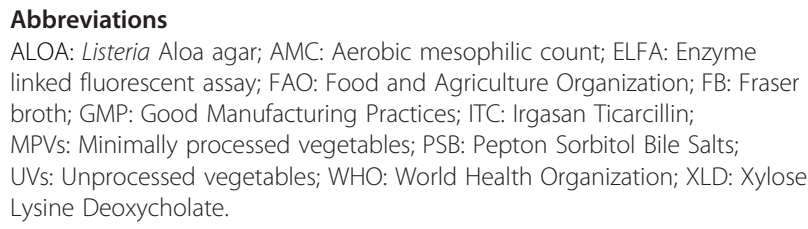

Authors' contributions

CC and AMDN designed and planned the study and drafted the manuscript. AA, CM and GO performed analysis and collected test results. All authors cooperated to the interpretation of the results. All authors read and approved the final manuscript. 


\section{Author details}

"Istituto Zooprofilattico Sperimentale della Sicilia "A. Mirri", via G. Marinuzzi 3, 90129 Palermo, Italy. ${ }^{2}$ Department of Science for Health Promotion and Mother-Child Care "G. D'Alessandro", University of Palermo, via del Vespro 133, 90127 Palermo, Italy.

Received: 20 October 2014 Accepted: 17 February 2015

Published online: 28 February 2015

\section{References}

1. Maffei DF, Silveira NFA, Catanozi MPLM. Microbiological quality of organic and conventional vegetables sold in Brazil. Food Control. 2013;29:226-30.

2. Baur JA, Pearson KJ, Price NL, Jamieson HA, Lerin C, Kalra A, et al. Resveratrol improves health and survival of mice on a high-calorie diet. Nature. 2006:444:337-42.

3. Jeong WS, Jun M, Kong AN. Nrf2: a potential molecular target for cancer chemoprevention by natural compounds. Antioxid Redox Signal. 2006;8:99-106.

4. Carlsen MH, Halvorsen BL, Holte K, Bøhn SK, Dragland S, Sampson L, et al. The total antioxidant content of more than 3100 foods, beverages, spices, herbs and supplements used worldwide. Nut J. 2010;9:3.

5. Astley SB, Elliott RM, Archer DB, Southon S. Evidence that dietary supplementation with carotenoids and carotenoid-rich foods modulates the DNA damage: repair balance in human lymphocytes. Br J Nutr. 2004;91:63-72.

6. Wood JG, Rogina B, Lavu S, Howitz K, Helfand SL, Tatar M, et al. Sirtuin activators mimic caloric restriction and delay ageing in metazoans. Nature. 2004:430:686-9.

7. Kensler TW, Wakabayashi N, Biswal S. Cell survival responses to environmental stresses via the Keap1-Nrf2-ARE pathway. Annu Rev Pharmacol Toxicol. 2007:47:89-116.

8. FAO/WHO (World Health Organization/Food and Agriculture Organization). Microbiological hazards in fresh leafy vegetables and herbs: meeting report. Microbiological Risk Assessment Series No. 14, Rome, Italy, 2008. [ftp://ftp.fao.org/docrep/fao/011/i0452e/i0452e00.pdf]

9. Warriner K, Huber A, Namvar A, Fan W, Dunfield K. Recent advances in the microbial safety of fresh fruits and vegetables. Adv Food Nutr Res. 2009;57:155-208.

10. Seow J, Ágoston R, Phua L, Yuk H-G. Microbiological quality of fresh vegetables and fruits sold in Singapore. Food Control. 2012;25:39-44.

11. European Commission. Health \& Consumer Protection Directorate-General [European Union]. Risk profile on the microbiological contamination of fruits and vegetables Eaten Raw. 2002. http://ec.europa.eu/food/fs/sc/scf/ out125_en.pdf.

12. Solomon EB, Yaron S, Matthews KR. Transmission of Escherichia coli O157:H7 from contaminated manure and irrigation water to lettuce plant tissue and its subsequent internalization. Appl Environ Microbiol. 2002;68:397-400.

13. Islam M, Morgan J, Doyle MP, Phatak SC, Millner P, Jiang X. Persistence of Salmonella enterica serovar typhimurium on lettuce and parsley and in soils on which they were grown in fields treated with contaminated manure composts or irrigation water. Foodborne Pathog Dis. 2004;1:27-35.

14. Rai PK, Tripathi BD. Microbial contamination in vegetables due to irrigation with partially treated municipal wastewater in a tropical city. Int J Environ Health Res. 2007;17:389-95.

15. Barker-Reid F, Harapas D, Engleitner S, Kreidl S, Holmes R, Faggian R. Persistence of Escherichia coli on injured iceberg lettuce in the field, overhead irrigated with contaminated water. J Food Prot. 2009;72:458-64.

16. Siddiqui MW, Chakraborty I, Ayala-Zavala JF, Dhua RS. Advances in minima processing of fruits and vegetables: a review. J Sci Ind Res. 2011;70:823-34.

17. FAO/WHO (World Health Organization/Food and Agriculture Organization). Microbiological hazards in fresh fruits and vegetables. Microbiological Risk Assessment Series (pre-publication version). 2008. [http://www.fao.org/food/ food-safety-quality/a-z-index/fresh-produce/en/]

18. Sagoo SK, Little CL, Ward L, Gillespie IA, Mitchell RT. Microbiological study of ready-to-eat salad vegetables from retail establishments uncovers a national outbreak of salmonellosis. J Food Prot. 2003;66:403-9.

19. Ragaert P, Devlieghere F, Debevere J. Role of microbiological and physiological spoilage mechanisms during storage of minimally processed vegetables. Postharvest Biol Technol. 2007:44:185-94.
20. Aycicek HÃ, Oguz U, Karci K. Determination of total aerobic and indicator bacteria on some raw eaten vegetables from wholesalers in Ankara, Turkey. Int J Hyg Environ Health. 2006;209:197-201.

21. Abadias M, Usall J, Anguera M, Solsona C, Viñas I. Microbiological quality of fresh, minimally-processed fruits and vegetables, and sprouts from retail establishments. Int J Food Microbiol. 2008:123:121-9.

22. Allende A, Aguayo E, Artés F. Microbial and sensory quality of commercial fresh processed red lettuce throughout the production chain and shelf life. Int J Food Microbiol. 2004;91:109-17.

23. Bohaychuk VM, Bradbury RW, Dimock R, Fehr M, Gensler GE, King RK, et al. A microbiological survey of selected Alberta-grown fresh produce from farmers' markets in Alberta, Canada. J Food Prot. 2009;72:415-20.

24. Santos MI, Cavaco A, Gouveia J, Novais MR, Nogueira PJ, Pedroso L, et al. Evaluation of minimally processed salads commercialized in Portugal. Food Control. 2012;23:275-81.

25. Europen Commission Regulation (EC) No 2073/2005 of 15 November 2005 on microbiological criteria for foodstuffs. Off J Eur Union L 338: 22.12.2005, 48:1-26.

26. Johnston LM, Jaykus L, Moll D, Martinez MC, Anciso J, Mora B, et al. A field study on the microbiological quality of fresh produce. J Food Prot. 2005:68:1840-7.

27. Mukherjee A, Speh D, Jones AT, Buesing KM, Diez-Gonzalez F. Longitudinal microbiological survey of fresh produce grown by farmers in the upper Midwest. J Food Prot. 2006;69:1928-36.

28. Sant'Ana AS, Landgraf M, Destro MT, Franco BD. Prevalence and counts of Salmonella spp. in minimally processed vegetables in São Paulo, Brazil. Food Microbial. 2011;28:1235-7.

29. Johannessen GS, Loncarevic S, Kruse H. Bacteriological analysis of fresh produce in Norway. Int J Food Microbiol. 2002;77:199-204.

30. Europen Commission Regulation (EC) No 333/2007 of 28 March 2007 laying down the methods of sampling and analysis for the official control of the levels of lead, cadmium, mercury, inorganic tin, 3-MCPD and benzo(a)pyrene in foodstuffs. Off J Eur Union L 88: 29.3.2007, 50:29-38.

\section{Submit your next manuscript to BioMed Central and take full advantage of:}

- Convenient online submission

- Thorough peer review

- No space constraints or color figure charges

- Immediate publication on acceptance

- Inclusion in PubMed, CAS, Scopus and Google Scholar

- Research which is freely available for redistribution 